International Journal of Advanced Research in Management (IJARM)

Volume 10, Issue 2, May - August 2019, pp. 01-14, Article ID: IJARM_10_02_001

Available online at

http://iaeme.com/Home/issue/IJARM?Volume=10\&Issue=2

Journal Impact Factor (2019): 8.5621 (Calculated by GISI) www.jifactor.com

ISSN Print: 0976 - 6324 and ISSN Online: 0976 - 6332

(C) IAEME Publication

\title{
LUXURY STATUS OF MALAYSIAN CONSUMERS
}

\author{
Hina Omer and Dr. Valliapan Raju \\ PGC, / Limkokwing University of Creative Technology, Malaysia 2019
}

\begin{abstract}
The Malaysian consumer identity has become a luxury brand phenomenon itself which is acknowledged through two consumer behavior theories "Expected Confirmation Theory and "Theory of Planned Behavior" for this study. This phenomenon is credited with philosophy of anthropology, perception, psychographic segmentation, business economics, environmental / social sciences, fashion management and consumer behavior studies to improve fashion and management knowledge. This thesis specifically spreads awareness on the brand factors being brand sustainability, brand congruence, brand identity, brand advertisement, brand perception and consumer identity and its relation to the dependent variable luxury brand awareness which were not exerted enough by fashion professionals in identifying a consumer status in Malaysia. How luxury brands over powers Malaysian consumer fashion identity to form associations such as a western fashion belonging, western fashion appreciation, western social acceptance and status as their only common fashion identity. Problem statement being lack of luxury fashion awareness on luxury brand advertisements by the Malaysian fashion professionals for consumers to blindly confine to other society fashion statements is potentially diminishing the Malaysian consumer fashion confidence.

The commonly preferred luxury identities from which fashion professionals could gain knowledge is supported through the exploratory quantitative field work of a purposively sampled questionnaire in Bukit Bintang Malaysia. Research objectives and research questions foregrounded the selection for field work in four malls around Kuala Lumpur region namely Suria KLCC, Times Square, Pavillion and Sangai Wong with only 302 respondents valid to prove the consumer luxury identity preferences of Malaysian consumers. Such a selection became pivotal to show that Malaysian consumers prefer being accepted as a western luxury style icon rather than initiating their personal fashion creation at first. How intense luxury brand advertisement numbs Malaysian consumer fashion preference and leads them to have a western status, pride, rank, class or belonging as their personal fashion statement before product purchase. How intense luxury brand advertisements impact consumer personal fashion initiation further adding value to fashion institutes in Malaysia is the backbone of this study.
\end{abstract}


Keywords: Luxury Brands, Consumer Identity, Status, Awareness, Brand Advertisement, Fashion Professionals.

Cite this Article: Hina Omer and Dr. Valliapan Raju, Luxury Status of Malaysian Consumers. International Journal of Advanced Research in Management, 10(2), 2019, pp. 01-14.

http://iaeme.com/Home/issue/IJARM?Volume $=10 \&$ Issue $=2$

\section{INTRODUCTION}

Luxury brands in Malaysia have influenced the consumer identity through the intense luxury brand advertisements maintaining a westernized social status and has always been a marvelous key for fashion public policy maker and controlling consumer identity. Sharing culture and experience through an apparel is what defines the nature of a fashion worn by the consumer. Study of luxury brand annual reports helped identifying awareness on brands factors control over consumer identity. Reason of luxury brand awareness for Malaysian consumers in PhD (Philosophy of Management) is because it needed an advanced academic perspective on fashion perception rather than focusing on the respondent's purchase intentions that have given enough attention by fashion professionals. This perception phenomenon was not exerted enough by fashion media, managers, professionals in Malaysia for a productive fashion/ identity development. It allowed the research to encompass a wider variety of disciplines including aesthetics, design, product development, economics, global business, marketing, consumer perception, operations, anthropology, psychology and sociology. Awareness is on the dependent variable being luxury brand awareness influenced by the respective independent brand factors brand sustainability brand congruence, brand identity, brand advertisement, brand perception and consumer identity in Malaysia to improve fashion knowledge for its individual fashion professional. Which demanded analysis on highlighting awareness on how Malaysian fashion consumers have come to such an understanding of fashion that results in disregarding their cultural/ personal image. Also enhancing the local Malaysian fashion designer's awareness of the consumer demand of luxury brand perception as their personal fashion statement.

It is a post positivist research which believes in portraying that luxury fashion brands being the style and status receptacles plays a crucial role in identity development and lowering Asian fashion confidence, it is a silent language that grasps a direct influence on consumer perception and outcomes of fashion prepost-behaviour. Socially aware fashion professionals should rightfully inform such outcomes in their brand advertisements. According to researcher's fashion knowledge, the dissertation focused on spreading awareness on luxury brand factors influencing Malaysian consumer identity in Bukit Bintang mall city, Klia airport and Langkawi to gather knowledge for questionnaire from an international fashion culture feedback. Basing on the Krejcie and Morgan (1970) theory of sample size 302 respondents were selected to prove such a practice. Statistical Analysis of the study is done through SPSS 25.0 version further evaluated through reliability, validity, Pearson correlation. Which proved the study's objectives, research questions and problem statement to help improve the future fashion industry in Malaysia.

\section{LITERATURE REVIEW}

Often consumers themselves do not know exactly how influences start to take place in their fashion inspiration before product purchase. "The human mind does not work in a linear way" says Kotler $(2009,160)$. Here they will be given more in depth knowledge on how a brand advertisement impacts consumer perception to implement a western luxury identity e.g instant change as the new consumer identity e.g Time Square Mall, Sangai Wang in Bukit Bintang; 
Kuala Lumpur and loss of personal/cultural fashion identities due to intense marketing of luxury brands. This phenomenon not being endeavored by fashion industry professionals, designers. The researcher will discuss the significance of the the negative or positive impact of the brand factors on the dependent variable being luxury brand awareness to improve fashion professional's knowledge" and the independent variables brand sustainability, brand congruence, brand identity, brand advertisement, brand perception and consumer identity.

After referencing through literature review on the world's top influential fashion brand luxury perceptions that are being mostly advertised in Malaysia are, Fendi, Channel, Michael Kors, Kate-Spade, Prada, Armani I Exchange AIX, Christian Dior, Ralph Lauren, Gucci, Burberry, Louis Vuitton, Tiffany \& Co, Manolo Blahnik, Coach, Tom Ford and Saint Lauren. Treat it as an introductory handbook on the influence of luxury brand advertisements numbing consumer identity and highlighting Malaysian fashion designers and consumers thought process fashion industry. Every brand has a look to sell and on every look you are accepting it to create a high-end personal class distinction which is quite evident in Malaysian fashion consumers.

\subsection{Malaysian Luxury Designer Fashion Shows from 2013-2019}

Their content is gathered from the videos found on social media platform YouTube from 2014-2018 to match with variables of the questionnaire. Due to confidentiality reasons of designers and them accepting the truth is always a tiring process the researcher found an alternative way to spread awareness on the dependent variable of this research. Each point of the dependent variable luxury brand awareness is supported with the evidence found on the fashion shows present form 2013 till 2018 KLFW. KLFW (Kuala Lumpur Fashion Week) is a platform for both old and new emerging designers of Malaysia from different ethnic Asian backgrounds. Andrew Tan being the co-founder conceptualized the platform to enhance Malaysian design platforms on 2013 for both Malaysian young and old designers to showcase their Ready to Wear Collections and highlight the creativity of Malaysian fashion industry to the local and international Consumers. But according to the data found through KLFW 20142018 fashion show videos on You Tube show cased majority European models which adds to the awareness focused for the purpose of this research. Yes, there is a minimal evidence of local models but not enough to showcase Malaysian luxury fashion statement. Since mostly Malaysian consumers confine to the idea of the model behind the product rather than the product itself .Out of 20 there are only 2 to 3 Malays models the rest all from Kazakhstan, European, Spain backgrounds. This evidence can be seen in a sequence according to the designer categorization and their choice of models in their fashion shows.

\section{Designer Malinda Looi}

In 2018 KLFW Malaysia published on August $10^{\text {th }}, 2018$ the designer just used total 15 models among which 3 Malay models and 12 European models to showcase her collection. Again supporting the dependent variable being Malaysian fashion professionals value a western luxury status over their ethnic style.

\section{Designer Fizi Woo}

In 2018 KLFW Malaysia published on August $10^{\text {th }}$, 2018 the designer used total of 24 models among which 3 Malaysian, 4 Asian and 17 European models to show case his collection. And in The Wedding KL show all models were European. Supporting fashion professionals valuing status more than style. 


\section{Designer JubahSouq}

In 2018 KLFW Malaysia published on August 10 ${ }^{\text {th }}$, 2018. The designer used total of 21 models among which 4 male Malay and 17 European models supporting status more than style.

\section{Designer A-Jane}

IN 2018 KLFW Malaysia published on August $18^{\text {th }}, 2018$ by Budiey Channel. The designer used total 9 models among which only one was a Malay model.

\section{Designer Farah Khan}

In 2017 KLFW Malaysia published on August $18^{\text {th }}, 2017$ the designer used 13 models among which only 2 were Malays and the rest all European models.

\section{Designer Nurita Harith}

In 2018 KLFW the designer published on August 10 ${ }^{\text {th }}, 2018$ used in total 16 models and all were European and fair Asian models that supports the western idea of beauty in Malaysia.

\section{Designer Zang Toi}

In his 2018 Spring Summer collection in New York published on Dec 11 $1^{\text {th }}, 2017$ by FF channel. He also showcased all European models to present his collection.

\section{Designer Khoon Hooi}

In his 2018 Fall/Autumn Show published on May $7^{\text {th }} .2018$. He used in total 14 models among which 4 were fair Asians, 2 African Models and 8 European models. Again showing the percentage of western idea of beauty more as compared to the local talents and other ethnic cultures in terms of model selection.

\section{Designer Bernard Chandran}

In his 2018 Bridal Spring fashion show published on November $30^{\text {th }} 2017$. He used 21 models among which only 1 was black, 1 was Indian and 17 were European and 2 were fair Asians.

\section{Designer Jimmy Choo}

In his 2018 campaign advertisement published on November $8^{\text {th }}, 2017$ with famous iconic model Cara Delevnige raised a lot of media concerns of women safety. Again showcasing western fashion control over Malaysian fashion professionals.

\section{Respondent Joe Shia}

On $18^{\text {th }}$ June 2014 KLFW fashion show published by KLFW on $22^{\text {nd }}$, July 2014. Mostly used all European models instead of a few Asian heritages with 2 Malays.

\section{Designer Alai Bastamam}

Alia Bastamam at KLFW 2017. Designer In total 17 models 3 were Asian, 2 Malays and 12 European models.

\section{Respondent Afiq Mohammed}

On 2015 KLFW fashion show published on August $17^{\text {th }}, 2015$. The designer in total used 12 models among which 3 were Asians, 1 Malay, 1 Indian and 7 were European. Showing a western idea of beauty that justifies the study's objective and matches with the results on consumer perception regarding the fashion professionals of Malaysia.

\section{Respondent Jovian Mandagie}

In 2013 KLFW fashion show published by KLFW on October $3^{\text {rd }}, 2013$. The designer used 9 models among which only 1 was Malay and 8 were European models.

\section{Respondent Silas Liew}

Silas Liew in KLFW 2013 published by KLFW on August $29^{\text {th }}, 2013$ in total used 10 models among which only 2 were Asians, 1 Malay and 7 were European. 


\section{RESEARCH METHODOLOGY}

This section discusses the research methodologies and techniques used during the journey of the study including research design, proposed model, instrument used, sampling technique, data collection and analysis approach. This randomized control trail experimental study was carried out on consumers of Bukit Bintang area Kuala Lumpur, Malaysia A total 302 adult subjects (both male and females) of aged $\geq 31-45$ a for this study.

Research Design: Quantitative

Research Type: Exploratory Descriptive, using Excel and SPSS version 25.0

Independent Variable: Brand sustainability, Brand congruence, brand identity, brand advertisements, brand perception and consumer identity

Dependent Variable: Luxury brand Awareness

\section{CONCEPTUAL FRAMEWORK}

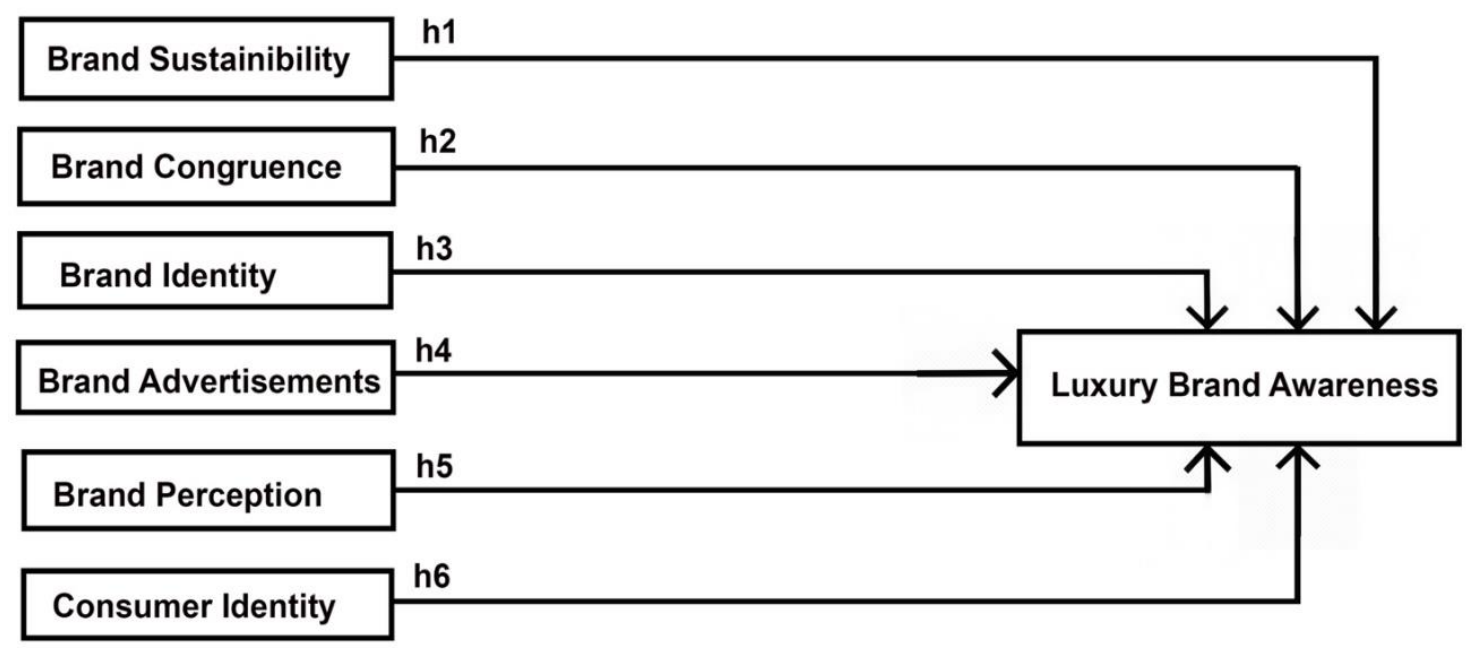

Independant Variables

Dependant Varibale

Figure 1 Conceptual Framework Showing the relationship between the independent variables and dependent variable.

Research Location: This study was based in Bukit Bintang Kuala Lumpur, KLIA airports and Langkawi Malaysia. Bukit Bintang is the area where most of the fashion consumers shop due to abundant variety of both international and local mall culture. All the high-end brands are mostly located in these vicinities of Malaysia.

Research Duration: April 2014 to July 2019.

Sample size: 302 patients. According to Krejice and Morgan theory of sample size.

Sample size calculation: The sample size was estimated on the basis of purposive sampling techniques according to the researcher's knowledge.

Subjects \& Selection method: The researcher targeted a few fashion industry locations individuals through the modelling experience and the other population was drawn mostly from s Bukit Bintang, KLIA airports and Langkawi Malaysia. Because it contains all the high-end luxury brand outlets in malls. The respondents were mainly youth age ranging from 31-35 and above; around 190 females and 112 males. 


\section{Research Instrument}

After literature review and field work for this study, a well-designed questionnaire was used to collect the data of the respondents respectively around the Bukit Bintang, KLIA airports and Langkawi. The questionnaire included two sections demographic characteristics such as age, gender, race, marital status, education level, salary range and work experience; section 2 covering the perception preferences of respondents for high-end brands support through the 5point Likert scale ranging from strongly disagree, disagree, neutral, agree and strongly agree. This 5-point Likert scale helped not only in gathering data on five preferences but made the findings for data evaluation quicker and less time consuming.

This type of instrument supported the nature of the study keeping the questions closed ended to find the exact problem statements and enhance knowledge on the research questions and objectives. Since every question was covering the basic fashion behaviors to which mostly consumers are attracted to e.g. rapid change, interaction, word of mouth, acceptance, satisfaction, recognition, association, conservativeness of high-end style, inspiration, quality, price, status, durability, loyalty, social media activity, impression, confidence, consciousness and freedom to be anyone you want through fashion. All these research questions were answered to support the objective through the association of these words into the questionnaire. Keeping the English simple in its pronunciation and wording so that consumers from all ages and races could comprehend the nature of the questionnaire easily. Few respondents had a difficulty in which was compensated through the self-administered questionnaire. Respondents protection was secure at times since the name was never asked for in the first place. This study did not require the name as it was focusing more on gender and age fashion preferences to spread awareness for fashion professionals

\begin{tabular}{|c|c|c|c|c|}
\hline \multicolumn{5}{|c|}{ Likert Scale } \\
\hline $\mathbf{1}$ & 2 & 3 & 4 & 5 \\
\hline Strongly Disagree & Disagree & Neutral & Agree & Strongly Agree \\
\hline
\end{tabular}

Source: Sekaran (2003)

\section{REGRESSION ANALYSIS}

The table below shows the respondents responses towards the Luxury brands preference in Malaysia. 
Luxury Status of Malaysian Consumers

Regression - Analysis

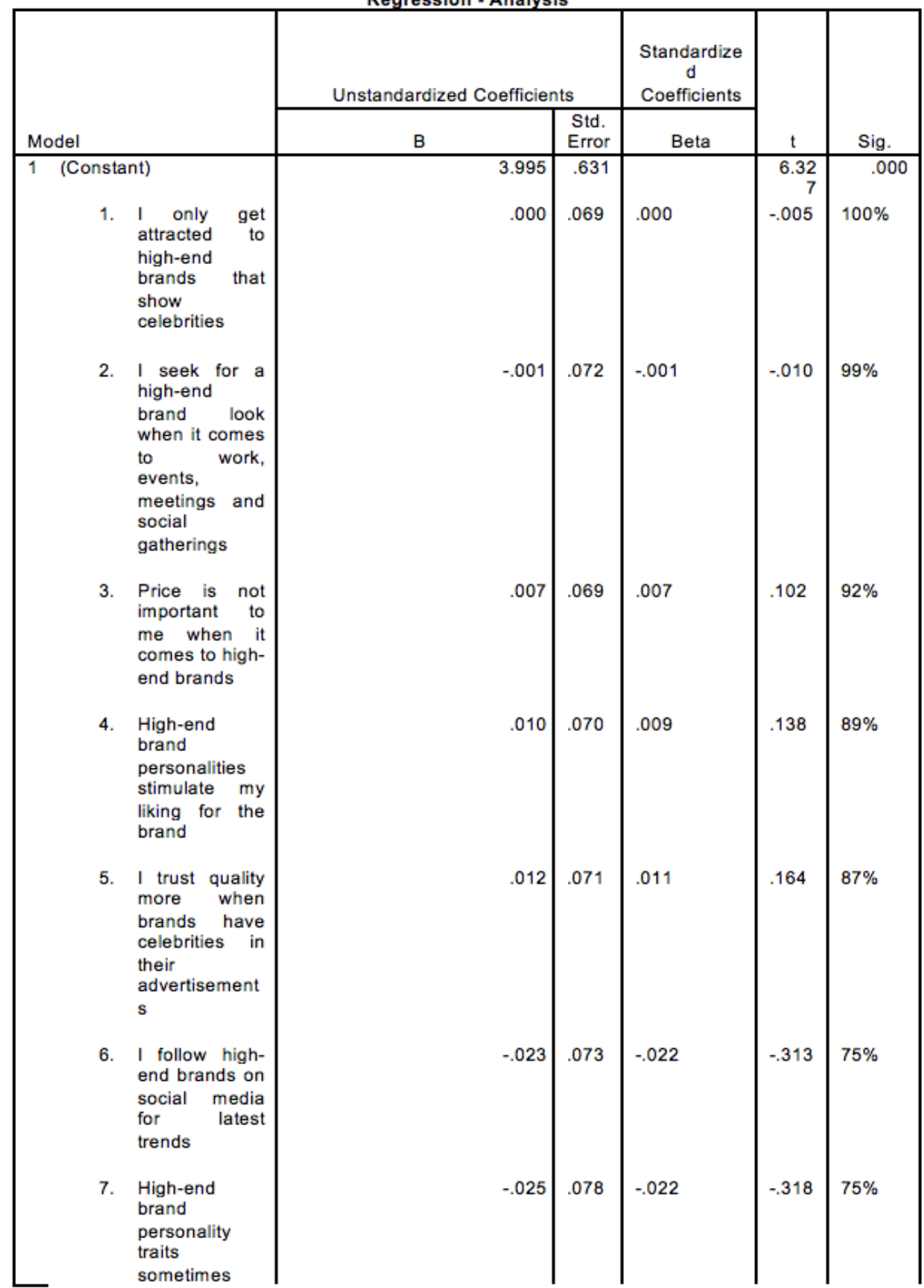




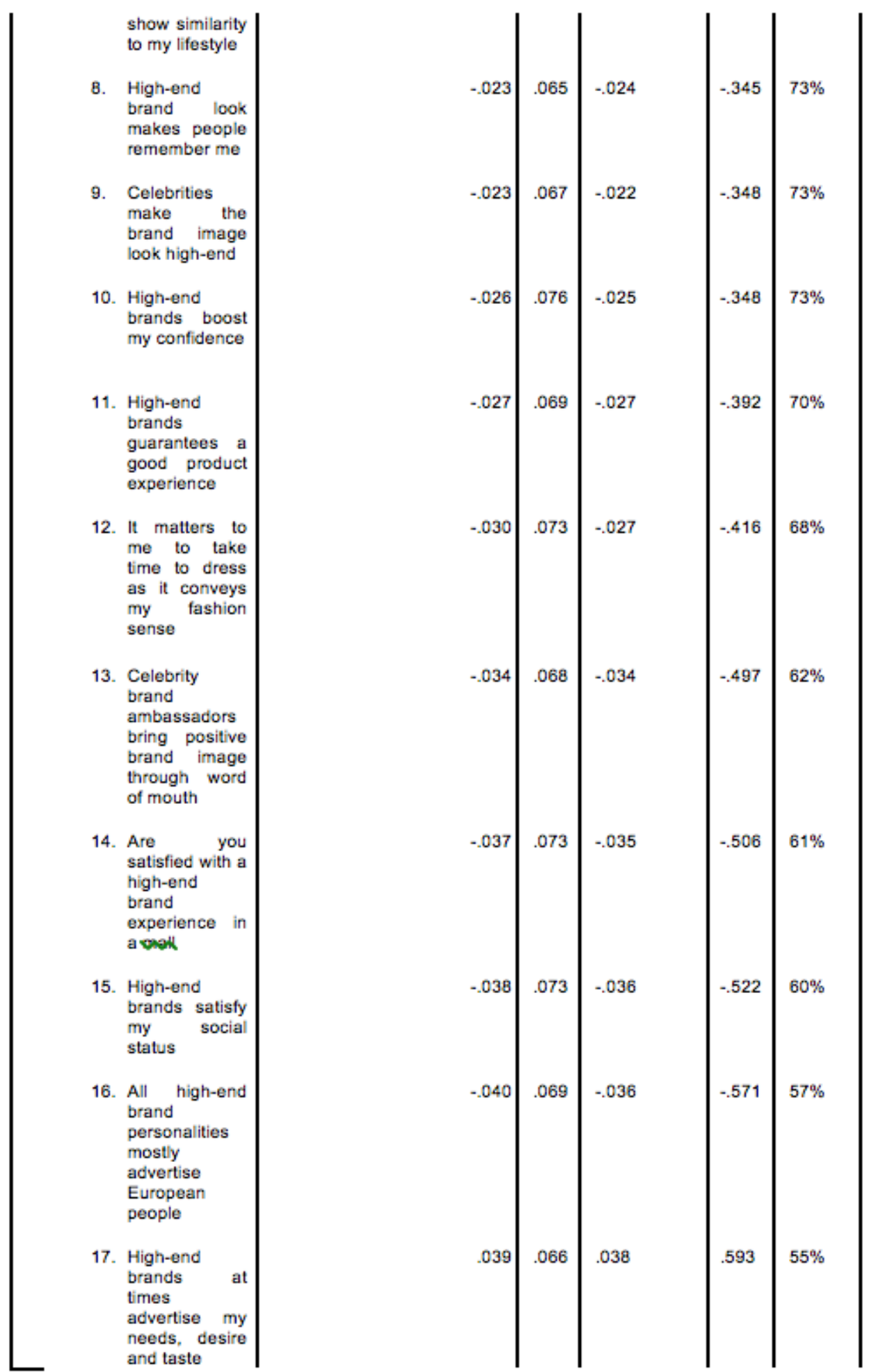


Luxury Status of Malaysian Consumers

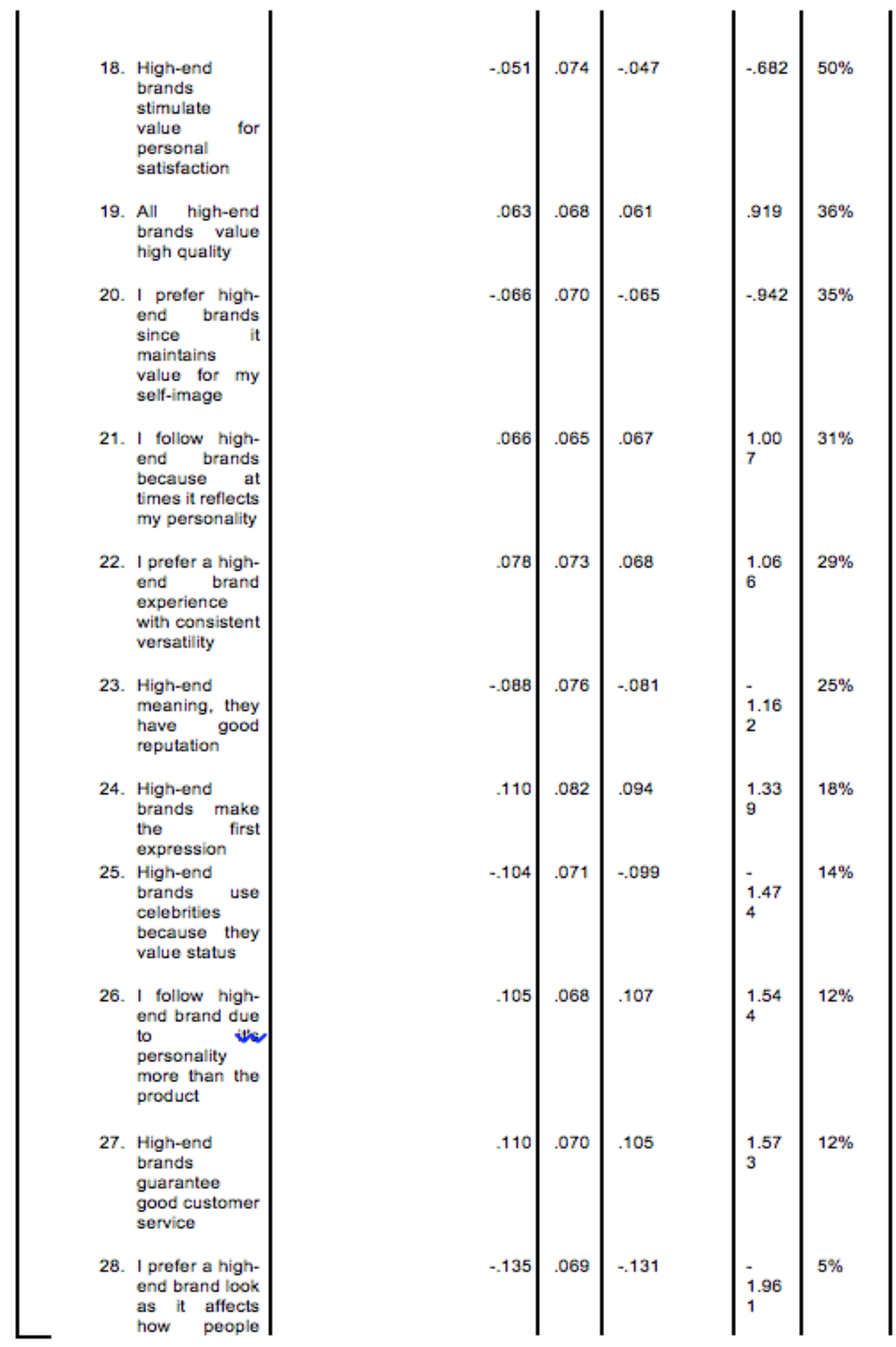




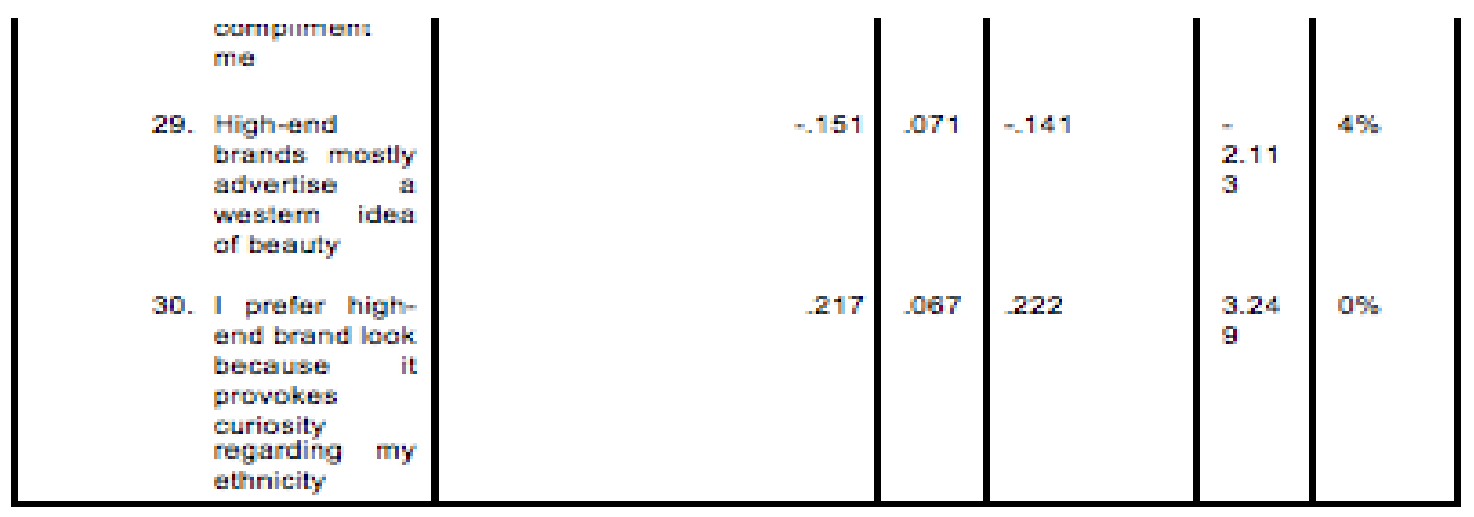

The factor that were considered initially for the study were gender, age, work experience, race, education level, marital status. The statement Price is not important to me when it comes to high-end brands showed a significance of $92 \%$. Salary range which is an indicative that the salary has no impact on the consumption of high end brands. It was found that the age and education levels are linked as mostly the individuals from the bachelors or diploma level are from 20-25 years of age and their need for high end brands is influenced by the presence of celebrities in the commercial or the portrayal of the advertisement creating a persona that someone who follows the high end brands are socially accepted. Mostly the reasons for the high - end brands have nothing with the personality of an individual but it's more because of the social constructs that exists in the culture in Malaysia. It focuses more on the social acceptability rather than the self-image. People tend to seek social acceptance \& according to the perception held by the individuals' high end brands guarantee that.

\section{RESULTS}

\begin{tabular}{|l|l|l|l|c|c|c|c|c|}
\hline \multicolumn{2}{|c|}{ Correlations } & $\begin{array}{c}\text { Awaren } \\
\text { ess of } \\
\text { Fashion } \\
\text { Brands } \\
\text { (DV) }\end{array}$ & $\begin{array}{c}\text { Brand } \\
\text { Sustainabi } \\
\text { lity (IV-1) }\end{array}$ & $\begin{array}{c}\text { Brand } \\
\text { Congrue } \\
\text { nce (IV- } \\
\text { 2) }\end{array}$ & $\begin{array}{c}\text { Bran } \\
\text { d } \\
\text { Identi } \\
\text { ty ( } \\
\text { IV-3) }\end{array}$ & $\begin{array}{c}\text { Brand } \\
\text { Advertise } \\
\text { ment (IV- } \\
\text { 4) }\end{array}$ & $\begin{array}{c}\text { Brand } \\
\text { Percepti } \\
\text { on (IV- } \\
\text { 5) }\end{array}$ & $\begin{array}{c}\text { Consu } \\
\text { mer } \\
\text { Identity } \\
\text { (IV-6) }\end{array}$ \\
\hline $\begin{array}{l}\text { Pearson } \\
\text { Correlat } \\
\text { ion }\end{array}$ & $\begin{array}{l}\text { Luxury } \\
\text { Brand } \\
\text { Awareness } \\
\text { (DV) }\end{array}$ & 1.000 & .582 & .572 & .680 & .703 & .678 & .121 \\
\cline { 2 - 9 } & $\begin{array}{l}\text { Brand } \\
\text { Sustainabil } \\
\text { ity (IV-1) }\end{array}$ & .582 & 1.000 & .296 & .355 & .266 & .217 & .050 \\
\hline $\begin{array}{l}\text { Brand } \\
\text { Congruenc } \\
\text { e (IV-2) }\end{array}$ & .572 & .296 & 1.000 & .370 & .267 & .306 & .142 \\
\cline { 2 - 9 } & $\begin{array}{l}\text { Brand } \\
\text { Identity ( } \\
\text { IV-3) }\end{array}$ & .680 & .355 & .370 & 1.000 & .418 & .371 & .099 \\
\hline $\begin{array}{l}\text { Brand } \\
\text { Advertise } \\
\text { ment (IV- } \\
\text { 4) }\end{array}$ & .703 & .266 & .267 & .418 & 1.000 & .541 & .152 \\
\hline $\begin{array}{l}\text { Brand } \\
\text { Perception } \\
\text { IV-5) }\end{array}$ & .678 & .217 & .306 & .371 & .541 & 1.000 & .292 \\
\cline { 2 - 9 } \\
$\begin{array}{l}\text { Consumer } \\
\text { Identity }\end{array}$ & .121 & .050 & .142 & .099 & .152 & .292 & 1.000 \\
\hline
\end{tabular}


Luxury Status of Malaysian Consumers

\begin{tabular}{|c|c|c|c|c|c|c|c|c|}
\hline & (IV-6) & & & & & & & \\
\hline \multirow[t]{7}{*}{$\begin{array}{l}\text { Sig. (1- } \\
\text { tailed) }\end{array}$} & $\begin{array}{l}\text { Luxury } \\
\text { Brand } \\
\text { Awareness } \\
\text { (DV) }\end{array}$ & & .000 & .000 & .000 & .000 & .000 & .018 \\
\hline & $\begin{array}{l}\text { Brand } \\
\text { Sustainabil } \\
\text { ity (IV-1) }\end{array}$ & .000 & & .000 & .000 & .000 & .000 & .191 \\
\hline & $\begin{array}{l}\text { Brand } \\
\text { Congruenc } \\
\text { e (IV-2) }\end{array}$ & .000 & .000 & & .000 & .000 & .000 & .007 \\
\hline & $\begin{array}{l}\text { Brand } \\
\text { Identity ( } \\
\text { IV-3) }\end{array}$ & .000 & .000 & .000 & & .000 & .000 & .043 \\
\hline & $\begin{array}{l}\text { Brand } \\
\text { Advertise } \\
\text { ment (IV- } \\
4 \text { ) }\end{array}$ & .000 & .000 & .000 & .000 & & .000 & .004 \\
\hline & $\begin{array}{l}\text { Brand } \\
\text { Perception } \\
\text { (IV-5) }\end{array}$ & .000 & .000 & .000 & .000 & .000 & & .000 \\
\hline & $\begin{array}{l}\text { Consumer } \\
\text { Identity } \\
\text { (IV-6) }\end{array}$ & .018 & .191 & .007 & .043 & .004 & .000 & \\
\hline
\end{tabular}

\section{RECOMMENDATION}

After reviewing scholarly literature and the dissertation findings it is recommended for fashion professionals to develop a balanced selection of models in their fashion shows, fashion awareness campaigns, conferences and fashion institutes should design a program for college students covering all industries to implement a fashion conscious behavior. Since all measures were based on self-reporting and respondents could choose whether to provide their responses, social desirability bias might exist in the results, particularly when high-end fashion sense is commonly promoted and encouraged by Malaysian designers as a socially desired status to enhance their fashion statements.

The study has shown that people are quite fond of developing a high-end status rather than a socially conscious fashion status. Which is adapted mostly by generation Y (millennials) the most susceptible to the vulnerability of adapting any new trends and not maintaining to one style. This phenomenon is succeeding to fragment their personal identities due to the desire for an instant new look, demotivating cultural values and personal fashion perception. If Malaysian fashion professionals do not propose a socially responsible fashion environment, then the consumers will slowly evolve towards adapting to a common western high-end selfimage.

The overall results obtained from the respondents mainly agreed to the fashion issues and other half being neutral. In most of the previous literature researches the middle point option in most occasions is neglected for having the exact impact of positive to negative from the survey or a questionnaire for a precise data evaluation. It is recommended for the fashion researchers to use the neutral position as it affects attitude response, showing the uninvolved respondents due to the lack of knowledge for the specific issue. Neutrality from the findings emerged to spread awareness on the ambivalent respondents that represented lack of fashion knowledge (Si and Cullen 1998). Neutrality of the research commands attention for future fashion professionals to not overlook this middle point but to investigate it further as a separate scale to enhance previous research gaps in fashion knowledge to evaluate attitude of the ambivalent respondents or generation Y (millennials). 


\section{ACKNOWLEDGEMENTS}

My Greatest thank you to Prof. Valliappan Raju for going out of his way to help understand a topic which is completely different for his field of interest. His management research ethics served the purpose of this study and together we both introduced how to enhance the value for a quantitative fashion consumer behavior study. Utmost thank you to Muhammad Farooq Buzdar who validated the Statistics to match with the conceptual model, research questions, and research questions.

\section{REFERENCES}

[1] Steven Kerr, Chester A. Schriesheim, Charles J. Murphy, Ralph M. Stogdill August (1974) Theory of Leadership based upon consideration and initiating structure literature. Pages 62-82. https://www.sciencedirect.com/science/article/pii/0030507374900373.

[2] Neale G. O'Connor July (1995) The control problem in public accounting firms: An empirical study of the impact of leadership style.

https://scholar.google.com.my/scholar?q=stogdill+1974+handbook+of+leadership+pdf\&h $1=$ en\&as_sdt $=0 \&$ as_vis $=1 \&$ oi $=$ scholart.

[3] Martijn Vastenburg and Robert J. Vroegindeweij (2009) Desinging an Awareness Display for Senior Home Care

Professionalshttps://www.academia.edu/511309/Designing_an_Awareness_Display_for_S enior_Home_Care_Professionals

[4] Muhammad Iqbal Bin Zamri (2015) A Study on the usage of fashion as tools of communication for awareness campaign.

https://www.academia.edu/35974760/a_study_of_fashion_as_tool_of_communication_for _awareness_campaign

[5] Pradnya P. Ambre and Sugandha Lad July (2017) Khadi awareness and promotion among youth.https://www.academia.edu/34264688/Khadi_Awareness_and_Promotion_among_Y outh

[6] Shiresha Manyam, Mary Swarnalatha. A \& Alapati Padama June (2018) Impact of social media on current fashion trends among youth.

[7] Rohti K. Dasgupta (2015) Contemporary south Asian youth cultures and the fashion landscapes.https://www.academia.edu/11700585/Contemporary_South_Asian_Youth_Cul tures_and_the_Fashion_landscape

[8] Margaret. B and Lucy Daly (2006) Buying behaviour for fast fashion. https://www.academia.edu/30619019/Buyer_behaviour_for_fast_fashion

[9] Miller, Laura (2004). Youth fashion and changing beautification practices. Japan's changing generations. "Are young people creating a new society ". https://www.academia.edu/22689588/Miller_2004_Youth_fashion_and_changing_beautifi cation_practices

[10] Adithya Reddy \& Gowtham Shivshankar (2010) legal protection for fashion designhttps://www.academia.edu/6348325/LEGAL_PROTECTION_FOR_FASHION_D ESIGNS

[11] Nehir E. Kursun (2013) Changing roles in contemporary fashion showshttps://www.academia.edu/12160704/ changing roles in contemporary fashion roles.

[12] Sue L. T. Mcgregor January (2013) Fostering Ideological Awareness For Consumer Professionals/ McGregor Monograph

https://www.academia.edu/4190426/Fostering_Ideological_Awareness_for_ConsumerPro fessionals?auto=download 
[13] Abela, J. R. Z., Webb, C. A., Wagner, C., Ho, M. H. R., \& Adams, P. (2006). The role of self-criticism, dependency, and hassles in the course of depressive illness: A multiwave longitudinal study. Personality and Social Psychology Bulletin, 32, 328-338. http://journals.sagepub.com/doi/10.1177/0146167205280911.

[14] Anthony, D. B., Holmes, J. G., \& Wood, J. V. (2007). Social acceptance and self-esteem: Turning the sociometer value. Journal of Personality ans social Psychology, 92, 10241039.

[15] Aspinwall, L. G., \& Taylor, S. E. (1992). Modeling cognitive adaptation: a longitudinal investigation of the impact of individual differences and coping on college adjustment and performance. Journal of Personality and Social Psychology, 63, 989-1003.

[16] Baccus, J. R., Baldwin, M. W., \& Packer, D. J. (2004). Increasing implicit self-esteem through classical conditioning. Psychological Science, 15, 498-502.

[17] Barden. R. C, Garber, J., Leiman, B., Ford, M. E., \& Masters, J. C. (1985). Factors governing the effective remediation of negative affect and its cognitive and behavioural consequences. Journal of Personality and Social Psychology, 49, 1040-1053.

[18] Baron, R. M., \& Kenny, D. A. (1986). The moderator-mediator variable distinction in social psychological research: Conceptual, strategic, and statistical considerations. Journal of Personality and Social Psychology, 51, 1173-1182.

[19] Aumeister, R. F., Campbell, J. D., Krueger, J. I., \& Vohs, K. D. (2003). Does High Selfesteem Cause Better Performance, Interpersonal Success, Happiness, or Healthier Lifestyles? Psychological Science in the Public Interest, 4, 1-44.

[20] Baumeister, R. F., \& Leary, M. R. (1995). The need to belong: Desire for interpersonal attachments as a fundamental human motivation. Psychological Bulletin, 117, 497-529

[21] Baumeister, R. F, \& Tice, D. M. (1990). Anxiety and social exclusion. Journal of Social and Clinical Psychology, 9, 165-195.

[22] Beike, D. R., \& Niedenthal, P. M. (1998). The process of temporal self-comparison in self-evaluation and life satisfaction. In P. T. P. Wong \& P. S. Fry (Eds.), The human quest for meaning: A handbook of psychological research and clinical applications (pp. 71-89). Mahwah, NJ: Erlbaum

[23] Bern, D. J. (1967). Self-perception: An alternative interpretation of cognitive dissonance phenomena. Psychological Review, 74, 183-200.

[24] Bern, D. J. (1972). Self-perception theory. In L. Berkowitz (Ed.). Advances in experimental social psychology (Vol. 6, pp. 1-62). New York: Academic Press.

[25] Blaney, P. H. (1986). Affect and memory: A review. Psychological Bulletin, 99, 229- 246.

[26] Blanton, H. (2001). Evaluating the self in the context of another: The three-selves model of social comparison assimilation and contrast. In G. B. Moskowitz (Ed.), Cognitive social psychology. The Princeton Symposium on the legacy and future of social cognition (pp. 75-87). Mahwah, NJ: Erlbaum.

[27] Bosson, J. K., Swann, W. B., Jr., \& Pennebaker, J. W. (2000). Stalking the perfect measure of implicit self-esteem: The blind men and the elephant revisited? Journal of Personality and Social Psychology, 79, 631-643.

[28] Brennan, K. A., \& Morris, K. A. (1997). Attachment styles, self-esteem, and patterns of seeking feedback from romantic partners. Personality and Social Psychology Bulletin, 23, 23-31

[29] Abdallat, J Tourism Hospit 2012 Actual Self-Image, Ideal Self-Image and the Relation between Satisfaction and Destination Loyalty. https://www.omicsonline.org/open- 
access/actual-self-image-ideal-self-image-and-the-relation-between-satisfaction-anddestination-loyalty-2167-0269.1000102.pdf.

[30] Sirgy MJ (1982) Self-Concept in Consumer Behaviour: A Critical Review. J Consum Res 9: 287-300. Sirgy MJ (1982) Self-Concept in Consumer Behaviour: A Critical Review. J Consum Res 9: 287-300.

[31] Sirgy MJ, Su C (2000) The Ethics of Consumer sovereignty in an Age of High Tech. J Bus Ethics 28: 1-14. https://link.springer.com/article/10.1023\%2FA\%3A1006285701103

[32] Grubb EL, Grathwhol HL (1967) Consumer Self-Concept, Symbolism and Market Behaviour: A Theoretical Approach. J Mark 31: 22-27. https://www.jstor.org/stable/1249461?seq=1\#page_scan_tab_contents.

[33] Deloizer MW (1971) A Longitudinal Study of the Relationship between Self- Image and Brand Image. Unpublished Ph.D. dissertation, University of North Carolina at Chapel Hill.

[34] Boone, L. and Kurtz, D. (2013) Contemporary Marketing. Belmont: Cengage Learning.https://writepass.com/journal/2017/01/marketing-and-branding-coco-chanel/ coco channel by Rodrigo Jan $10^{\text {th }} 2017$.

[35] Burrow, Jan $15^{\text {th }}$ (2008) Marketing. Belmont: Cengage Learning. https://books.google.com.my/books/about/Marketing.html?id=GzwBUZpXVhkC\&redir_e $\mathrm{sc}=\mathrm{y}$

[36] Cant, M., Strydom, J., Jooste, C. and du Plessis, P. April $1^{\text {st }}$ (2009) Marketing Management. Cape Town: Juta and Company Ltd. 624 pages https://www.amazon.com/Marketing-Management-M-C-Cant/dp/0702171883.

[37] Carr, T. (2012) Chanel, Zegna top competitors for perceived brand experience: study. Luxury Daily. 257 pages Available from http://www.luxurydaily.com/chanelachieves-best-perceived-customer-experience-study/ [Accessed: 20 December 2014].

[38] Susan Elizabeth (Suze) Wilson (2013) Thinking Differently about Leadership: A critical History of the form and formation of leadership studies. Victoria University of Wellington http://www.criticalmanagement.org/files/Wilson\%282013\%29.pd

[39] Gary Yukl 20 $0^{\text {th }}$ March (2016) Managerial Leadership: A Review of Theory and Researchhttps://www.researchgate.net/profile/Gary_Yukl/publication/237935280_Manage rial_Leadership_A_Review_of_Theory_and_Research/links/56eeac3708aed17d09f8201b. pdf gary yukhi managerial leadership: a review of theory and research

[40] Jhon Adair's Action-Centered Leadership (2017) https://www.businessballs.com/leadership-styles/action-centred-leadership-john-adair$4335 /$.

[41] Mathew McCormack May $4^{\text {th }}(2016)$, Relevance of Leadership Skills in Todays's Fashion Industry https://www.linkedin.com/pulse/relevance-leadership-skills-todays-fashionindustry-matthew-mccormack.

[42] Rajesh Kumar April $1^{\text {st }}$ (2016) 6 Technology Trends That will impact Fashion Industry https://www.entrepreneur.com/article/273353

[43] Maya Singer April 21 ${ }^{\text {st }}$ (2015) The Clothing Insurrection: It's It's Time to Take On the Fashion Supply Chain http://www.vogue.com/article/fashion-supply-chain-environmentalimpact 